\title{
PENGARUH KOMPETENSI PROFESIONAL GURUTERHADAP KUALITAS PEMBELAJARAN DI RAUDHATUL ATHFAL TANGERANG
}

\author{
Nisa Tsabitah ${ }^{1}$, Nila Fitria ${ }^{1}$ \\ Program Studi Pendidikan Guru Pendidikan Anak Usia Dini, Fakultas Psikologi dan \\ Pendidikan, Universitas Al-Azhar Indonesia, Jl. Sisingamangaraja, Kebayoran Baru, RT \\ 02/01, Jakarta Selatan, 12110 \\ E-mail: Nilafitria@uai.ac.id
}

\begin{abstract}
ABSTRAK- Kompetensi Profesional Guru adalah kemampuan yang dimiliki oleh guru sesuai dengan standar kompetensi profesional sedangkan kualitas pembelajaran adalah terpenuhinya kriteria dalam pelaksanaan pembelajaran. Kompetensi profesional guru merupakan salah satu hal yang membuat pembelajaran dapat berkualitas.Penelitian ini bertujuan untuk mengetahui pengaruh kompetensi profesional guru terhadap kualitas pembelajaran di RA Kecamatan Ciledug.Penelitian ini menggunakan metode survei dan sampel penelitian ini adalah 30 guru RA kelas TK A dan B tahun ajaran 2016/2017, yang dipilih menggunakan teknik simple random sampling.Teknik pengumpulan data peneliti menggunakan angket/ kuesioner tertutup dengan menggunakan alat ukur skala likert, jenis data interval.Teknik analisis data yang digunakan adalah analisis Product moment dengan program software SPSS versi 21,0. Hasil penelitian ini menunjukan bahwa terdapat Pengaruh Kompetensi Profesional Guru terhadap Kualitas Pembelajaran di RA Kecamatan Ciledug Kota Tangerang: hipotesis dapat diterima dimana "Terdapat Pengaruh signifikan pada Kompetensi Profesional Guru terhadap Kualitas Pembelajaran di RA Kecamatan Ciledug Kota Tangerang dengan besaran pengaruh sebesar 49,3\%.”
\end{abstract}

Kata kunci: Kompetensi Profesional Guru, Kualitas, Pembelajaran

ABSTRACT-Teacher Professional Competence is the ability possessed by the teacher in accordance with the standards of professional competence while the quality of learning is fulfilling the criteria in implementing learning. Teacher professional competence is one of the things that makes learning quality. This study aims to determine the effect of teacher professional competency on the quality of learning in RA District Ciledug. This study used a survey method and the sample of this study were 30 RA teachers in kindergarten A and B school year 2016/2017, which was selected using a simple random sampling technique. Data collection techniques researchers used closed questionnaires / questionnaires using a Likert scale measuring instrument, type of interval data. The data analysis technique used was Product moment analysis with SPSS software version 21.0. The results of this study indicate that there is an effect of Teacher Professional Competence on Learning Quality in RA Ciledug District, Tangerang City: a hypothesis is acceptable where "There is a significant effect on Teacher Professional Competence on Learning Quality in RA Ciledug District, Tangerang City with a magnitude of $49.3 \%$."

Keywords: Teacher Professional Competence, Quality, Learning. 


\section{PENDAHULUAN}

A. Lata

\section{ar Belakang}

ualitas adalah ukuran baik buruknya sesuatu, kadar, mutu, derajad/taraf (kepandaian/ kecakapan, dan sebagainya). Sementara, Pembelajaran adalah proses interaksi antara anak didik dan pendidik dengan melibatkan orang tua serta sumber belajar pada suasana belajar bermain di satuan atau program PAUD (Peraturan Menteri Pendidikan dan Kebudayaan Republik Indonesia Nomor 137 Tahun 2014).

Menurut Wahyuni, Yuliantina dan Ritayanti (2015: 1) Kualitas pembelajaran dapat diukur dan ditentukan oleh sejauh mana kegiatan pembelajaran dapat mengubah perilaku anak ke arah yang sesuai dengan tujuan kompetensi yang telah ditetapkan. Menurut Mulyasa (2006: 210-211) Keberhasilan perilaku pembelajaran anak usia dini dapat dilihat: 1. Sekurang - kurangnya $85 \%$ peserta didik memiliki kemauan belajar yang tinggi, anak - anak berpartisipasi aktif dalam proses pembelajaran. 2. Materi yang dikomunikasikan sesuai dengan kebutuhan anak dan mereka memandang bahwa hal tersebut akan sangat berguna bagi kehidupan kelak. 3. Dapat menumbuhkan minat belajar baik lanjut atau continuing. 4. Anak - anak menjadi insan yang kreatif dan mampu menghadapi berbagai permasalahan yang dihadapinya. 5. Anak - anak tidak memberikan pengaruh negatif terhadap masyarakat lingkungannya dengan cara apapun.

Oleh karena itu pihak sekolah diharapkan mampu merancang, mengembangkan dan melaksanakan kegiatan pembelajaran yang sesuai dengan karakteristik, kebutuhan dan perkembangan anak, yang mana hal ini dapat menghasilkan perilaku anak ke arah yang sesuai dengan tujuan kompetensi yang telah ditetapkan. Untuk itu penting bagi pihak sekolah memperhatikan kualitas pembelajaran dalam menerapkan proses pendidikan anak usia dini. Apabila kualitas pembelajaran baik maka anak usia dini tersebut dapat memperoleh perkembangan yang optimal dan dapat memanfaatkan peluang pada masa emas tersebut sedangkan apabila kualitas pembelajaran tidak baik maka anak usia dini tidak dapat memperoleh perkembangan yang optimal dan tidak dapat memanfaatkan peluang pada masa emas tersebut. Clark dalam Sudjana \& Rivai (2001: 39) menyimpulkan bahwa hasil belajar siswa di sekolah $70 \%$ dipengaruhi oleh kemampuan siswa dan 30\% dipengaruhi oleh lingkungan. Sedangkan salah satu lingkungan belajar yang paling dominan mempengaruhi hasil belajar di sekolah adalah kualitas pembelajaran.

Berdasarkan hasil observasi pada bulan Januari tahun 2017 di salah satu Raudhatul Athfal (RA) daerah Ciledug, pembelajaran banyak dilakukan dengan menggunakan Lembar Kerja (LK) saja, pembelajaran dilakukan dengan metode ceramah sehingga guru yang lebih bersifat aktif dan anak cenderung pasif. Terbatasnya jumlah media pembelajaran di sekolah, juga menjadi faktor dalam keberlangsungan pembelajaran. Berdasarkan observasi, diketahui pula bahwa pembelajaran yang diberikan memberi dampak negative pada perilaku anak sebagai akibat dari pembelajaran yang tidak sesuai dengan prinsip pembelajaran anak usia dini.

Perilaku negatif tersebut antara lain: 1. anak - anak tidak mau membereskan mainan ketika disuruh oleh guru; 2. Anak terlihat pasif karena kurang dilibatkan saat pembelajaran di kelas seperti: guru jarang meminta anak untuk bercerita di depan kelas sehingga saat dipanggil ke depan untuk bercerita anaknya kesulitan dalam bercerita; 3. Anak kurang memahami materi penjumlahan seperti saat menjawab soal penjumlahan yang ada di LKA terlihat anak masih kebingungan menjawab soal dan yang ada salah; 4. saat proses pembelajaran terlihat anak jarang mengajukan pertanyaan karena pembelajarannya tidak menggunakan metode tanya jawab tetapi menggunakan metode ceramah. Perilaku perilaku yang ditunjukan anak berdasarkan hasil observasi dapat dikatakan belum sesuai dengan perilaku yang seharusnya dimunculkan melalui pembelajaran yang berkualitas.

Pada dasarnya pembelajaran dapat dikatakan berkualitas apabila lingkungan pembelajaran dapat mendukung dengan baik, yang termasuk dalam lingkungan salah satunya adalah guru. Kenyataan permasalahan tersebut dapat diperbaiki apabila guru mempunyai kompetensi profesional sebagai salah satu syarat pembelajaran berkualitas. Menurut Peraturan Menteri Pendidikan dan Kebudayaan Republik Indonesia Nomor 137 Tahun 2014 adapun cakupan kompetensi 
tersebut meliputi empat (4) kompetensi yang salah satunya adalah kompetensi profesional. Alasan peneliti memilih kompetensi profesional adalah karena berdasarkan hasil Uji Kompetensi Guru (UKG) di Banten, kompetensi profesional guru masih di bawah Kriteria Ketuntasan Minimal (KKM). Informasi tersebut dapat diketahui dari media online, yang berjudul "Hasil UKG Kemendikbud tahun 2015”. Berdasarkan info yang diperoleh diketahui bahwa hasil UKG yang sudah digelar pada bulan November tahun 2015 adalah umumnya masih di bawah standar KKM yang sudah ditentukan, dimana KKM UKG tahun 2015 adalah sebesar 5,5. Hasil UKG Profesional di Banten sebesar 52,20 dengan nilai maksimal 100.00 dan minimal 10.00. Rendahnya kompetensi professional guru juga diperkuat dengan hasil observasi dan wawancara yang dilakukan pada Januari tahun 2017 disalah satu RA daerah Ciledug. Informasi yang diperoleh adalah masih ada beberapa guru yang kurang memiliki pemahaman dalam pembuatan dan pengembangan Rencana Kegiatan Harian (RKH) yang sesuai dengan kondisi sekolah tersebut. Selain itu, guru tidak menguasai bahan ajar, serta guru tidak mampu mengelola kelas sehingga anak tidak nyaman dalam mengikuti proses belajar mengajar di kelas. Berdasarkan permasalahan di atas maka perlu dilakukan penelitian dengan judul "Pengaruh Profesional Guru terhadap Kualitas Pembelajaran di Raudhatul Athfal Kecamatan Ciledug Kota Tangerang."

\section{B. Identifikasi Masalah}

Berdasarkan latar belakang di atas, maka dapat dilakukan identifikasi masalah sebagai berikut:

1. Proses pembelajaran di RA masih berpusat pada guru bukan peserta didik.

2. Keterbatasan media yang digunakan oleh guru pada saat proses pembelajaran seperti puzzle, balok dan buku cerita.

3. Pembelajaran kebanyakan menggunakan LK (Lembar Kerja).

4. Rendahnya kemampuan guru dalam menguasai bahan ajar secara mendalam.

5. Kurangnya pemahaman guru dalam pembuatan dan pengembangan RKH (Rencana Kegiatan harian) yang sesuai dengan kondisi sekolah.
6. Rendahya kemampuan guru dalam mengelola kelas.

\section{Pembatasan Masalah}

Dari identifikasi masalah yang ada, maka masalah dibatasi pada kompetensi professional guru dan kualitas pembelajaran.

\section{Rumusan Masalah}

Adapun rumusan masalah dari penelitian ini adalah: "apakah terdapat pengaruh Kompetensi Profesional Guru terhadap Kualitas Pembelajaran di Raudhatul Athfal, Ciledug, Tangerang?". Berdasarkan rumusan masalah tersebut maka tujuan penelitian ini adalah untuk mengetahui "pengaruh Kompetensi Profesional Guru terhadap Kualitas Pembelajaran di Raudhatul Athfal, Ciledug, Tangerang."

\section{TINJAUAN PUSTAKA}

\section{A. Kualitas Pembelajaran}

Menurut Suprihatiningsih (2016: 4), kualitas atau mutu adalah hasil atau outcome dari suatu proses pembelajaran atau suatu hasil yang diukur menurut ukuran atau standar terbaik yang telah atau pernah dicapai dalam suatu proses pembelajaran. Tujuan dari kualitas ini adalah agar dapat berubah menjadi sesuatu yang lebih baik, menurut Glaser (dalam Uno, 2010: 40) kualitas lebih mengarah kepada sesuatu yang baik. Sedangkan pengertian pembelajaran menurut Degeng (dalam Rohman dan Amri, 2013: 179), pembelajaran atau pengajaran adalah upaya untuk membelajarkan siswa. Dalam pengertian ini secara implisit dalam pengajaran terdapat kegiatan memilih, menetapkan, mengembangkan, metode untuk mencapai hasil pengajaran yang diinginkan. Pemilihan, penetapan, dan pengembangan metode ini didasarkan pada kondisi pengajaran yang ada.Kegiatan ini pada dasarnya merupakan inti dari perencanaan pembelajaran.

Untuk dapat melaksanakan proses pembelajaran dengan baik, maka salah satu hal yang harus diperhatikan adalah komponen yang terdapat dalam proses pembelajaran. beberapa komponen oleh Brown (dalam Sanjaya, 2011: 9) diantaranya: siswa, tujuan, kondisi, sumber belajar dan hasil belajar. Agar pelaksanaan pembelajaran berjalan dengan 
baik dan hasilnya dapat diandalkan, maka perbaikan pengajaran diarahkan pada pengelolaan pembelajaran. Dalam hal ini bagaimana peran strategi pembelajaran merupakan kegiatan pokok yang merupakan dimensi dari peningkatan kualitas pembelajaran. Strategi pembelajaran meliputi seluruh kegiatan/ tahapan - tahapan (Riyanto, 2009: 141) yang meliputi: Persiapan pembelajaran, pelaksanaan kegiatan pembelajaran dan evaluasi hasil program belajar dan perbaikan program kegiatan pembelajaran.

Evaluasi merupakan unsur penting dalam proses pembelajaran, karena melalui evaluasi dapat diketahui apakah tujuan yang direncanakan atau perubahan tingkah laku sebagai hasil belajar dapat tercapai atau tidak, serta seberapa jauh keberhasilan belajar tersebut dapat dicapai. Jika pembelajaran itu berhasil melalui evaluasi maka pembelajaran tersebut dapat dikatakan berkualitas. Untuk memudahkan proses evaluasi secara keseluruhan berikut adalah bagian-bagian dari evaluasi yaitu evaluasi konteks, evaluasi input, evaluasi proses dan evaluasi hasil (Hakiim, 2009: 163).

Kualitas pembelajaran dapat berhasil apabila memenuhi inidikator kualitas pembelajaran. Uno (2010: 158) menuliskan indikator kualitas pembelajaran adalah sebagai berikut: 1. Menata bahan ajar yang akan diberikan selama satu semester; 2. Menata bahan ajar yang akan diberikan setiap pertemuan; 3. Memberikan pokok materi; 4. Menetapkan materi; 5. Memberikan tugas;. 6. Membuatkan format penilaian.; 7. Menggunakan berbagai metode; 8 . Menggunakan berbagai media; 9. Menggunakan berbagai teknik pembelajaran; 10. Memberikan motivasi atau menarik perhatian; 11. Menjelaskan tujuan pembelajaran kepada siswa; 12. Mengingatkan kompetensi prasyarat; 13. Memberikan stimulus; 14. Memberikan petunjuk belajar; 15. Menimbulkan penampilan siswa; 16 . Memberikan umpan balik; 17. Menilai penampilan; dan 19. Menyimpulkan.

Agar mendapatkan pembelajaran yang berkualitas maka seorang guru PAUD harus memahami pembelajaran di TK/RA karena bagaimanapun pembelajaran di TK berbeda dengan pembelajaran di SD, SMP dan SMA untuk itu guru perlu memahami: apa saja aspek perkembangan anak TK pada masa itu, karakteristik pembelajaran anak usia dini (AUD), dan prinsip pembelajaran AUD serta metode pembelajaran AUD.

\section{B. Kompetensi Profesional Guru}

Menurut Trianto (2011: 26), Kompetensi profesional ialah kemampuan penguasaan materi bidang profesi secara luas dan mendalam. Misalnya untuk mencapai keberhasilan pendidikan, sistem pendidikan harus ditata dan dirancang oleh orang - orang yang ahli dibidangnya yang ditandai dengan kompetensi sebagai persyaratannya. Seorang guru harus menguasai ilmu pengetahuan dan ahli dalam menyampaikan pengetahuan hal ini diperkuat oleh seorang ahli pendidikan yang menyatakan bahwa: "teacher is a person who causes a person to know or be able to do something or give a person knowledge or skil" (Nurdin, 2002: 7). Guru adalah seseorang yang ahli dalam menyampaikan pengetahuan atau keterampilan kepada orang lain.

Menurut Villege-Reimer dalam buku Musfah (2015: 18), guru merupakan faktor pertama dan penentu (kunci) keberhasilan pembelajaran. Gary dan Margaret (dalam Mulyasa, 2009: 21) mengemukakan bahwa guru yang efektif dan kompeten secara profesional memiliki karakteristik sebagai berikut:

1. Memiliki kemampuan menciptakan iklim belajar yang kondusif.

2. Kemampuan mengembangkan strategi dan manajemen pembelajaran.

3. Memiliki kemampuan memberikan umpan balik (feedback) dan penguatan (reinforment), dan

4. Memiliki kemampuan untuk peningkatan diri.

Berdasarkan Peraturan Menteri Pendidikan dan Kebudayaan Republik Indonesia Nomor 137 tahun 2014 tentang Standar Nasional Pendidikan Anak Usia Dini, kompetensi profesional pendidik guru adalah: 1 . Menelaah materi; 2. Mengorganisasikan materi; 3. Merumuskan tujuan setiap kegiatan pengembangan; $4 . \quad$ Menganalisis perkembangan anak usia dini dalam setiap bidang pengembangan; 5. Memilih materi; 6 . Mengorganisasikan kegiatan pengembangan secara kreatif sesuai dengan tingkat perkembangan anak usia dini; 7. Melakukan 
reflektif terhadap kinerja sendiri secara terus menerus; dan, 8. Memanfatkan hasil refleksi dalam rangka peningkatan keprofesionalan.

Berdasarkan beberapa penjelasan di atas dapat dikatakan bahwa kompetensi profesional guru adalah kemampuan yang dimiliki oleh guru sesuai dengan standar kompetensi profesional guru PAUD yang berkenaan dengan mengembangkan materi dalam bentuk tema yang dikembangkan dalam proses kegiatan belajar mengajar, memiliki struktur dan konsep bidang keilmuwan yang mencakup 6 aspek perkembangan anak usia dini yaitu aspek fisik-motorik, kognitif, bahasa, sosialemosional, seni, dan moral agama, dapat merancang berbagai kegiatan dan mengembangkan keprofesionalan.

\section{Kerangka Berpikir}

Guru merupakan salah satu komponen yang dapat memajukan pendidikan, karena guru merupakan tokoh utama yang berinteraksi dengan anak di dunia pendidikan. Untuk itu guru juga dituntut mempunyai kompetensi profesional karena hal itu yang mempengaruhi bagaimana guru akan mengajar anak-anak didiknya dengan tepat dan benar. Kompetensi profesional berupa penguasaan: 1. mengembangkan materi, stuktur, dan konsep bidang keilmuwan yang mendukung serta sejalan dengan kebutuhan dan tahapan perkembangan anak usia dini; 2 . Merancang berbagai kegiatan pengembangan secara kreatif sesuai dengan tahapan perkembangan anak usia dini; dan, 3. Mengembangkan keprofesional secara berkelanjutan dengan melakukan tindakan reflektif diharapkan mampu mempengaruhi kualitas pembelajaran yang meliputi penerapan: 1. Strategi pengorganisasian pembelajaran dalam hal ini berkaitan dengan menata bahan ajar dan format penilaian yang sesuai dengan perkembangan anak usia dini; dan, 2. Strategi penyampaian pembelajaran yang berkaitan dengan metode, media dan teknik pembelajaran yang sesuai dengan perkembangan anak usia dini. Strategi pengelolaan pembelajaran berkaitan dengan motivasi, stimulasi, dan tujuan pembelajaran yang sesuai dengan perkembangan anak usia dini.

\section{Hipotesis Penelitian}

Berdasarkan kajian teori dan kerangka berpikir, yang telah dikemukakan di atas maka hipotesis penelitian ini adalah "Terdapat Pengaruh Kompetensi Profesional Guru terhadap Kualitas Pembelajaran di RA Kecamatan Ciledug Kota Tangerang, dengan kata lain "Ha diterima dan Ho ditolak."

\section{METODE PENELITIAN}

\section{A. Tujuan Penelitian}

Tujuan penelitian ini adalah untuk mengetahui pengaruh kompetensi profesional guru terhadap kualitas pembelajaran di RA Kecamatan Ciledug, Tangerang tahun ajaran 2016 - 2017.

\section{B. Tempat \& Waktu Penelitian}

Penelitian ini dilakukan di 6 sekolah RA Kecamatan Ciledug, Tangerang.yaitu RA Nurul Amin (Jl. Akasia rt.03/04 No.22 Kelurahan Tajur), RA Amali (Komp. Puri Kartika Blok E6-8), RA Mulia Az-Zahra (Jl. Wiru Indah No.2A rt.02/01), dan RA Nurul Iman (Jl. Hos Cokroaminoto Gg. Masjid 2), RA Jami'atul Khair (J1 Masjid Tajur No 16 Kelurahan Tajur), dan RA Nurul Huda (Jl Raden Fatah, Gg Masjid Rt 01/11 Kelurahan Sudimara Selatan). Subjek adalah guru RA. Waktu penelitian dilakukan selama 5 bulan dimulai bulan Januari 2017.

\section{Metode Penelitian}

Metode yang dilakukan dalam penelitian ini adalah metode kuantitatif dengan pendekatan survei eksplanatif. Menurut Budiharto (2008: 29-30), survei ekplanatif (analitik) adalah survei yang berusaha menjawab pertanyaan bagaimana dan mengapa karena penelitian ini berusaha menjelaskan bagaimana dan mengapanya suatu keadaan.

\section{Populasi \& Sample Penelitian}

1. Populasi Penelitian

Menurut Sugiyono (2007: 61), populasi adalah wilayah generalisasi yang terdiri atas: objek atau subyek yang mempunyai kualitas dan karakteristik tertentu yang ditetapkan oleh peneliti untuk dipelajari dan kemudian ditarik kesimpulannya. Adapun populasi dari penelitian ini adalah guru yang mengajar pada tahun ajaran 2016-2017 sejumlah 123 
guru di 22 RA Kecamatan Ciledug Kota Tangerang.

2. Sampel Penelitian

Menurut Sugiyono (2007: 62) sampel adalah bagian dari jumlah dan karakterisitik yang dimiliki populasi. Pengambilan sampel menggunakan teknik Simple Random Sampling. Sampel yang terpilih dalam penelitian ini adalah 30 Guru TK A dan TK B dari 6 RA yaitu: RA Amali, Nurul Iman, RA Mulia Az-zahra, RA Nurul Amin, RA Nurul Huda dan RA Jami'atul Khair.

\section{E. Variabel Penelitian}

1. Variabel-variabel yang akan diteliti adalah:

a. Kompetensi profesional guru (variable independen/bebas).

b. Kualitas pembelajaran (variable dependen/terikat).

2. Skala Kompetensi Profesional Guru

a. Definisi Konseptual

Kompetensi profesional guru adalah kemampuan yang dimiliki oleh guru sesuai dengan standar kompetensi profesional guru PAUD yang berkenaan dengan mengembangkan materi dalam bentuk tema yang dikembangkan dalam proses kegiatan belajar mengajar, memiliki struktur dan konsep bidang keilmuwan yang mencakup 6 aspek perkembangan anak usia dini yaitu aspek fisik-motorik, kognitif, bahasa, sosial-emosional, seni, dan moral agama, dapat merancang berbagai kegiatan dan mengembangkan keprofesionalan.

b. Definisi Oprasional

Kompetensi profesional guru adalah pengukuran yang menggunakan sub variabel sebagai berikut: 1). penguasaan mengembangkan materi, struktur dan konsep bidang keilmuwan yang mendukung serta sejalan dengan kebutuhan dan tahapan perkembangan anak usia dini 2) penguasaan merancang berbagai kegiatan pengembangan secara kreatif sesuai dengan tahapan perkembangan anak usia dini. 3) penguasaan mengembangkan keprofesional secara berkelanjutan dengan melakukan tindakan reflektif.

3. Skala Kualitas Pembelajaran

a. Definisi Konseptual

Kualitas pembelajaran adalah sesuatu yang memiliki nilai baik yang ditandai dengan terpenuhinya kriteria dalam pelaksanaan pembelajaran yang berkaitan dengan penerapan strategi pengorganisasian, penerapan penyampaian pembelajaran dan penerapan strategi pengelolaan pembelajaran sehingga dapat mengetahui apakah pembelajaran itu dapat berhasil atau tidak.

b. Definisi Oprasional

Kualitas pembelajaran adalah pengukuran yang menggunakan sub variabel sebagai berikut: 1). Penerapan strategi pengorganisasian pembelajaran dalam hal ini berkaitan dengan menata bahan ajar dan format penilaian yang sesuai dengan perkembangan anak usia dini. 2). Penerapan strategi penyampaian pembelajaran dalam hal ini berkaitan dengan metode, media dan teknik pembelajaran yang sesuai dengan perkembangan anak usia dini. 3). Penerapan strategi pengelolaan pembelajaran dalam hal ini berkaitan dengan motivasi, stimulasi, dan tujuan pembelajaran yang sesuai dengan perkembangan anak usia dini.

\section{F. Instrumen Penelitian}

Penelitian ini menggunakan angket berskala Likert yang terdiri dari pernyataan favourabe dan unfavourable dengan pernyataan tertutup. Skala ini menggunakan model Likert dengan 5 alternatif jawaban, yaitu sangat sering, sering, kadang-kadang, pernah, tidak pernah. Berdasarkan hasil uji coba pada 30 guru di 6 RA Kecamatan Ciledug, pernyataan untuk Kompetensi Profesional Guru memiliki 26 butir pernyataan setelah di uji validitas dan reliabilitas menghasilkan 18 butir pernyataan dengan Cronbach Alpha sebesar 0,9035. Sedangkan 
Kualitas Pembelajaran memiliki 26 butir pernyataan setelah di uji validitas dan reliabilitas menghasilkan 14 butir pernyataan dengan Cronbach Alpha sebesar 0,878271.

\section{G. Teknik Analisis Data}

Data hasil penelitian di analisis dengan menggunakan statistik deskriptif dan inferensial. Statistik deskriptif yang digunakan antara lain: mean, median, modus, standart deviation, variance, range, minimum, maximum, dan sum. Infrensial yang digunakan adalah regresi sederhana. Sebelum data dianalisis dengan statistik regresi terlebih dahulu dipenuhi persyaratan analisisnya yakni data harus berdistribusi normal

\section{HASIL DAN PEMBAHASAN}

\section{A. Hasil Penelitian}

1. Deskripsi Umum

a. Deskripsi Umum Tempat

Raudhatul Athfal adalah lembaga pendidikan anak usia dini yang dinaungi oleh Kementerian Agama dan terletak di Kecamatan Ciledug Kota Tangerang. Raudhatul Athfal di daerah Ciledug berjumlah 22 sekolah dengan guru berjumal 123 orang. Dalam penelitian ini hanya digunakan 13 sekolah dan 60 guru, dengan rincian 7 sekolah untuk pengambilan data uji coba dan 6 sekolah untuk pengambilan data sebenarnya.

b. Karakteristik Responden

1) Jenis Kelamin Responden

Tabel 1. Jenis Kelamin Responden

\begin{tabular}{|r|r|r|r|r|}
\hline & Frequency & Percent & $\begin{array}{r}\text { Valid } \\
\text { Percent }\end{array}$ & $\begin{array}{c}\text { Cumulative } \\
\text { Percent }\end{array}$ \\
\hline Perempuan & 28 & 93.3 & 93.3 & 93.3 \\
Valid laki-laki & 2 & 6.7 & 6.7 & 100.0 \\
Total & 30 & 100.0 & 100.0 & \\
\hline
\end{tabular}

2) Usia Responden

Tabel 2. Usia Responden

\begin{tabular}{|c|r|r|r|r|}
\hline & Frequency & Percent & $\begin{array}{c}\text { Valid } \\
\text { Percent }\end{array}$ & $\begin{array}{c}\text { Cumulative } \\
\text { Percent }\end{array}$ \\
\hline .00 & 3 & 10.0 & 10.0 & 10.0 \\
Valid 20-30 Tahun & 8 & 26.7 & 26.7 & 36.7 \\
40-50 Tahun & 8 & 26.7 & 26.7 & 63.3 \\
Total & 11 & 36.7 & 36.7 & 100.0 \\
\hline
\end{tabular}

3) Jabatan Responden

Tabel 3 Jabatan Responden

\begin{tabular}{|l|r|r|r|r|}
\hline & Frequency & Percent & Valid Percent & $\begin{array}{c}\text { Cumulative } \\
\text { Percent }\end{array}$ \\
\hline .00 & 11 & 36.7 & 36.7 & 36.7 \\
TK A & 8 & 26.7 & 26.7 & 63.3 \\
TK B & 11 & 36.7 & 36.7 & 100.0 \\
Total & 30 & 100.0 & 100.0 & \\
\hline
\end{tabular}

4) Pendidikan Responden

Tabel 4. Pendidikan Terakhir Responden

\begin{tabular}{|l|l|l|l|l|}
\hline & Frequency & Percent & $\begin{array}{l}\text { Valid } \\
\text { Percent }\end{array}$ & $\begin{array}{l}\text { Cumulative } \\
\text { Percent }\end{array}$ \\
\hline .00 & 2 & 6.7 & 6.7 & 6.7 \\
S1 & 23 & 76.7 & 76.7 & 83.3 \\
SMA & 5 & 16.7 & 16.7 & 100.0 \\
Total & 30 & 100.0 & 100.0 & \\
\hline
\end{tabular}

5) Program Studi Responden

Tabel 5. Program Studi Responden

\begin{tabular}{|l|l|l|l|l|}
\hline & Frequency & Percent & $\begin{array}{l}\text { Valid } \\
\text { Percent }\end{array}$ & $\begin{array}{l}\text { Cumulative } \\
\text { Percent }\end{array}$ \\
\hline .00 & 6 & 20.0 & 20.0 & 20.0 \\
PAI & 7 & 23.3 & 23.3 & 43.3 \\
STKIP & 1 & 3.3 & 3.3 & 46.7 \\
PKN & 1 & 3.3 & 3.3 & 50.0 \\
PGSD & 1 & 3.3 & 3.3 & 53.3 \\
PG PAUD & 6 & 20.0 & 20.0 & 73.3 \\
Akuntansi & 2 & 6.7 & 6.7 & 80.0 \\
PGTK & 1 & 3.3 & 3.3 & 83.3 \\
Tarbiyah & 2 & 6.7 & 6.7 & 90.0 \\
IPS & 2 & 6.7 & 6.7 & 96.7 \\
Matematika & 1 & 3.3 & 3.3 & 100.0 \\
Total & 30 & 100.0 & 100.0 & \\
\hline
\end{tabular}


6) Lama Mengajar Responden

Tabel 6. Lama Mengajar Responden

\begin{tabular}{|l|l|l|l|l|}
\hline & Frequency & Percent & $\begin{array}{l}\text { Valid } \\
\text { Percent }\end{array}$ & $\begin{array}{l}\text { Cumulative } \\
\text { Percent }\end{array}$ \\
\hline .00 & 5 & 16.7 & 16.7 & 16.7 \\
$1-5$ tahun & 5 & 16.7 & 16.7 & 33.3 \\
$5-10$ tahun & 6 & 20.0 & 20.0 & 53.3 \\
$10-15$ & 6 & 20.0 & 20.0 & 73.3 \\
$\begin{array}{l}\text { Tahun } \\
15-20\end{array}$ & 8 & 26.7 & 26.7 & 100.0 \\
Tahun & 30 & 100.0 & 100.0 & \\
Total & 30 & &
\end{tabular}

7) Status Kepegawaian Responden

Tabel 7. Status Kepegawaian Responden

\begin{tabular}{|l|l|l|l|l|}
\hline & Frequency & Percent & $\begin{array}{l}\text { Valid } \\
\text { Percent }\end{array}$ & $\begin{array}{l}\text { Cumulative } \\
\text { Percent }\end{array}$ \\
\hline .00 & 10 & 33.3 & 33.3 & 33.3 \\
Non PNS & 15 & 50.0 & 50.0 & 83.3 \\
GTT & 1 & 3.3 & 3.3 & 86.7 \\
GTY & 4 & 13.3 & 13.3 & $10 p .0$ \\
Total & 30 & 100.0 & 100.0 & \\
\hline
\end{tabular}

2. Deskripsi Data Hasil Penelitian

a. Kompetensi Profesional Guru

1) Mencari lebar interval untuk mempermudah kategori persentase variabel sangat tinggi, tinggi, sedang, rendah dan sangat rendah.

Hasil SPSS diketahui bahwa kompetensi skor maksimal sebesar 86,00 dan skor minimal sebesar 39,00. Jika dihitung menggunakan rumus mencari interval maka 9,6 dibulatkan menjadi 10.

2) Menetapkan klasifikasi Kompetensi Profesional Guru.

Berdasarkan skor maksimal, skor minimum dan lebar interval dapat diklasifikasikan sebagai berikut:

Tabel 8. Rekapitulasi interval dan kategori tentang kompetensi Profesional Guru di RA se kecamatan Ciledug.

\begin{tabular}{|l|l|l|}
\hline Interval & Frekuensi & Kategori \\
\hline $39,00-48,00$ & 2 & Sangat rendah \\
\hline $49,00-58,00$ & 6 & Rendah \\
\hline $59,00-68,00$ & 14 & Sedang \\
\hline $69,00-78,00$ & 5 & Tinggi \\
\hline $79,00-88,00$ & 3 & Sangat tinggi \\
\hline Jumlah & 30 & \\
\hline
\end{tabular}

b. Kualitas Pembelajaran

1) Mencari lebar interval untuk mempermudah kategori persentase variabel sangat tinggi, tinggi, sedang, rendah dan sangat rendah.

Hasil SPSS diketahui bahwa Kualitas Pembelajaran skor maksimal sebesar 70,00 dan skor minimal sebesar 33,00. Jika dihitung menggunakan rumus mencari interval maka 7,6 dibulatkan menjadi 8.

2) Menetapkan klasifikasi Kualitas Pembelajaran

Tabel 9. Rekapitulasi interval dan kategori tentang Kualitas Pembelajaran di RA se kecamatan Ciledug.

\begin{tabular}{|l|l|l|}
\hline Interval & Frekuensi & Kategori \\
\hline $33,00-40,00$ & 1 & sangat rendah \\
\hline $41,00-48,00$ & 7 & Rendah \\
\hline $49,00-56,00$ & 5 & Sedang \\
\hline $57,00-64,00$ & 13 & Tinggi \\
\hline $65,00-72,00$ & 4 & Sangat tinggi \\
\hline Jumlah & 30 & \\
\hline
\end{tabular}

3. Uji Persyaratan Analisis

a. Uji Normalitas

Uji normalitas merupakan salah satu bagian dari uji persyaratan analisis data atau uji asumsi klasik, artinya sebelum melakukan analisis yang sebenarnya, data penelitian tersebut harus di uji kenormalan distribusinya. Keputusan uji normalitas adalah jika nilai signifikansi lebih besar dari 0,05 maka data tersebut berdistribusi normal. Sebaliknya jika nilai signifikansi lebih kecil dari 0,05 maka data tersebut tidak berdistribusi normal. Berikut adalah tabel hasil perhitungan uji normalitas data : 
Tabel 10. Uji Normalitas

\begin{tabular}{|ll|r|r|}
\hline & & Kompetensi & Kualitas \\
\hline $\mathrm{N}$ & & 30 & 30 \\
Normal Parametersab & Mean & 64.0333 & 55.7667 \\
& Std. & 10.45345 & 8.92375 \\
& Deviation & & \\
Most Extreme & Absolute & .094 & .175 \\
Differences & Positive & .086 & .112 \\
Kolmogorov-Smirnov Z & Negative & -.094 & -.175 \\
Asymp. Sig. (2-tailed) & .515 & .957 \\
\hline
\end{tabular}

Berdasarkan hasil uji normalitas pada tabel 10 di atas, maka dapat dinyatakan bahwa data Kompetensi Profesional Guru dan Kualitas Pembelajaran berdistribusi normal, dengan demikian maka dapat digunakan untuk diambil inferensinya.

b. Uji Hipotesis

1) Persamaan Regresi Linear
Sederhana

Tabel 11. Coefficients

\begin{tabular}{|l|l|l|l|l|l|}
\hline \multirow{2}{*}{ Model } & \multicolumn{2}{|l|}{$\begin{array}{l}\text { Unstandardized } \\
\text { Coefficients }\end{array}$} & $\begin{array}{l}\text { Standardized } \\
\text { Coefficients }\end{array}$ & \multirow{2}{*}{ Sig. } \\
\cline { 2 - 4 } & $\mathrm{B}$ & Std. Error & Beta & & \\
\hline (Constant) & 17.390 & 7.451 & & 2.334 & .027 \\
Kompetensi & .599 & .115 & .702 & 5.217 & .000 \\
\hline
\end{tabular}

Persamaan regresinya adalah $\mathrm{Y}=17,930+0,599 \mathrm{X}$, maka dengan demikian dapat dikatakan bahwa setiap kenaikan dalam kompetensi profesional guru (X) akan menaikan Kualitas pembelajaran sebesar 0,599 pada nilai awal 17,930.Karena nilai koefisien regresi bernilai positif $(+)$, maka dengan demikian dapat dikatakan bahwa Kompetensi Profesional Guru (X) berpengaruh positif terhadap Kualitas Pembelajaran (Y). Untuk itu sebelum menentukan hipotesis penelitian maka dilakukan pengujian signifikan dan linearitas regresi.

2) Uji Signifikansi dan Linearitas Regresi Sederhana
a) Uji Signifikansi (Uji F)
Uji $F$ dilakukan untuk mengetahui signifikansi persamaan regresi, berikut adalah tabel Uji F :

Tabel 12. Anova Table Regresi

Sederhana

\begin{tabular}{|c|c|c|c|c|c|c|}
\hline \multicolumn{2}{|c|}{ Model } & $\begin{array}{l}\text { Sum of } \\
\text { Squares }\end{array}$ & $\mathrm{Df}$ & $\begin{array}{l}\text { Mean } \\
\text { Square }\end{array}$ & F & Sig. \\
\hline \multirow{3}{*}{1} & Regression & 1138.253 & 1 & 1138.253 & 27.214 & $.000^{b}$ \\
\hline & Residual & 1171.113 & 28 & 41.825 & & \\
\hline & Total & 2309.367 & 29 & & & \\
\hline
\end{tabular}

Maka diketahui bahwa nilai Ftabel sebesar 12. Karena nilai Fhitung 27,214 lebih besar dari nilai $\mathrm{F}$ tabel 12 . Maka dapat ditarik kesimpulan bahwa Kompetensi Profesional Guru (X) berpengaruh signifikan terhadap Kualitas Pembelajaran (Y).

b) Uji Linearitas

Tabel 13. Anova Tabel Linear Sederhana

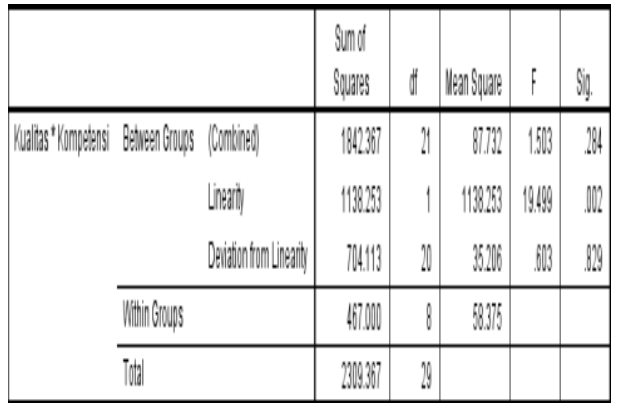

Jadi kesimpulannya berdasarkan hasil uji linearitas pada output tabel "Anova table" di atas, diketahui bahwa nilai Sig. Deviation From Linearity Sebesar 0. 829, karena nilai Sig. 0,829>0,05 dan nilai $F$. deviation atau Fhitung sebesar 0.603 karena F hitung 0,603 < Ftabel 3,15 maka dapat disimpulkan bahwa $\mathrm{Ho}$ ditolak dan $\mathrm{Ha}$ diterima, artinya terdapat persamaan regresi $17,930+$ 0,599 linear. 
c) Uji $\mathrm{R}^{2}$ (Analisis Determinasi).

Tabel 14.Model Summary

\begin{tabular}{|l|l|l|l|l|}
\hline $\begin{array}{l}\text { Mode } \\
1\end{array}$ & $R$ & $R$ Square & $\begin{array}{l}\text { Adjizsted } \\
\text { Square }\end{array}$ & $\begin{array}{l}\text { Std. Error of } \\
\text { the Estimate }\end{array}$ \\
\hline 1 & $.702^{3}$ & .493 & .475 & 6.46726 \\
\hline
\end{tabular}

Dari output di atas diketahui nilai $\mathrm{R}$ Square sebesar 0,493. Nilai ini mengandung arti bahwa pengaruh Kompetensi Profesional Guru (X) terhadap Kualitas Pembelajaran (Y) adalah sebesar 49,3\% sedangkan $\quad 50,7 \%$ Kulitas Pembelajaran dipengaruhi oleh variabel yang lain yang tidak dibahas dalam penelitian ini.

\section{B. Pembahasan}

Hasil analisis data yang dilakukan peneliti menunjukkan beberapa hal yang dapat disampaikan bahwa dari 30 responden yang merupakan guru-guru RA di Kecamatan Ciledug menunjukan data bahwa berdasarkan hasil tabel frekuensi pada 5 kategori, pada variabel Kompetensi Profesional Guru (X), nilai $\mathrm{F}$ paling dominan berjumlah 14 pada kolom kategori sedang dengan jarak interval 59,00 - 68,00. Sedangkan hasil dari tabel frekuensi pada variabel Kualitas Pembelajaran (Y), nilai F paling dominan berjumlah 13 pada kolom kategori tinggi dengan jarak interval $57,00-64,00$. Sedangkan bila pada 3 kategori variabel kompetensi Profesional (X) dan kualitas pembelajaran (Y) masuk dalam kategori sedang dan tinggi.

Hal ini diperkuat dari hasil perhitungan karakteristik responden dimana pendidikan terakhir guru di RA se kecamatan Ciledug didominasi lulusan S1 Jurusan pendidikan. Hasil data angket deskripsi menunjukan bahwa indikator kualitas yang perlu ditingkatkan lagi pada kualitas pembelajaran yaitu pada indikator: 1. Menetapkan materi (kesulitan menetapkan tema); 2. Menilai penampilan anak (melakukan penilaian anecdote); dan, 3. Membuatkan format penilaian (memahami penilaian anecdote). Hal ini perlu ditingkatkan karena menurut Uno (2010: 158) pembelajaran dapat berkualitas apabila dapat memenuhi semua indikator kualitas pembelajaran.

Sedangkan hasil data deskripsi angket Kompetensi Profesional Guru di RA Kecamatan Ciledug yang perlu ditingkatkan yaitu pada indikator: 1. mengorganisasikan materi sejalan dengan tahapan perkembangan anak usia dini (membuat kegiatan belajar sesuai minat anak); 2. merumuskan tujuan berbagai kegiatan pengembangan secara kreatif; 3. memilih materi berbagai kegiatan pengembangan secara kreatif; 4. Mengorganisasikan berbagai kegiatan pengembangan secara kreatif (mengembangkan kegiatan pembelajaran terpadu melalui aktivitas fieldtrip); dan 5. memanfatkan hasil refleksi untuk mengembangkan keprofesional secara berkelanjutan dalam pernyataan. Hal ini perlu ditingkatkan karena menurut Peraturan Menteri Pendidikan Anak dan Kebudayaan Republik Indonesia Nomor 137 tahun 2014, guru dapat dikatakan memiliki kompetensi profesional apabila memenuhi semua indikator kompetensi profesional guru tersebut.

Upaya dalam meningkatkan kualitas pembelajaran melalui kompetensi profesional guru sesuai yang dikemukakan oleh VillegeReimer dalam Musfah (2015: 18) yang menyatakan bahwa guru merupakan faktor pertama dan penentu (kunci) keberhasilan pembelajaran, juga keberhasilan implementasi kebijakan, usaha-usaha inovatif, atau demokratisasi pendidikan.Guru di sini adalah guru yang memiliki 4 kompetensi salah satunya kompetensi profesional. Hasil dari analisis data tersebut dapat dijadikan bahan maupun sebagai acuan apa saja yang harus ditingkatkan maupun diperbaiki dari kedua variabel tersebut.

Hasil data Penelitian yang dilakukan peneliti sesuai dengan hasil penelitian sebelumnya, yang dilakukan oleh Titik Haryanti dalam skripsi yang berjudul "Pengaruh Kompetensi Profesional Guru Terhadap Minat Belajar Mata Pelajaran Fiqih Pada Siswa Kelas VIII MTs Yasu'a Pilangwetan Kec.Kebonagung.Kab. Demak Tahun Ajaran 2009/2010. Kesimpulan yang diperoleh berdasarkan analisa selanjutnya dengan menggunakan rumus product moment diperoleh 0,517 dikonsultasikan dengan product moment atau $\mathrm{n}=1$ pada taraf signifikan $5 \%=0.279$ dan pada taraf signifikan $1 \%=$ 
0.361 , ternyata nilai $\mathrm{r}$ berada di atas $\mathrm{r}$ tabel product moment sehingga hipotesis yang diajukan diterima. Dengan demikian untuk hipotesis yang berbunyi" ada pengaruh yang positif antara kompetensi profesional guru terhadap minat belajar mata pelajaran fiqih pada siswa kelas VIII MTs Yasu'a Pilangwetan, Kec.Kebon Agung, Kab. Demak Tahun Ajaran 2009/2010.

\section{Temuan Penelitian.}

Berdasarkan hasil penelitian mengenai kompetensi profesional guru dan kualitas pembelajaran, diperoleh informasi sebagai berikut:

1. Hasil observasi menunjukkan bahwa guru menyampaikan materi tapi tidak tuntas dan tidak menguasai materi. Sementara menurut Asian Institute For Teacher Education (dalam Uno, 2010: 243), kompetensi profesional guru yaitu salah satunya mampu menangani materi yang ditugaskan kepadanya.

2. Berdasarkan hasil wawancara diketahui bahwa PTK sering dilakukan namun saat observasi PTK tidak terlihat. PTK merupakan salah satu cara untuk mengembangkan keprofesionalan guru. Hal ini terdapat dalam Peraturan Menteri Pendidikan dan Kebudayaan Republik Indonesia Nomor 137 tahun 2014 tentang Standar Nasional Pendidikan Anak Usia Dini dimana dalam salah satu indikator Kompetensi Profesional Guru adalah guru mengembangkan keprofesional secara berkelanjutan dengan melakukan tindakan reflektif.

3. Berdasarkan hasil wawancara pula diketahui bahwa guru-guru mengembangkan tema sesuai dengan kehidupan sehari-hari. Namun pada saat observasi, guru tidak terlihat mempraktekkan tema sesuai dengan kehidupan sehari - hari pada hari itu. Berdasarkan Peraturan Menteri Pendidikan dan Kebudayaan Republik Indonesia Nomor 137 tahun 2014 tentang Standar Nasional Pendidikan Anak Usia Dini, salah satu indikator guru yang profesional adalah memilih materi sesuai dengan tahapan perkembangan anak usia dini dan salah satu pemilihan materi adalah pemilihan tema.
Adapun hasil angket yang tidak sesuai dengan hasil observasi dan wawancara terlihat pada kualitas pembelajaran:

1. Hasil observasi menunjukkan guru tidak melakukan appersepsi pembelajaran, namun pada hasil angket guru selalu melakukan apersepsi sesuai tema sebelum kegiatan pembelajaran setiap kali pertemuan. Padahal seharusnya appersepsi dilakukan untuk menggambarkan informasi terkait dengan tema yang akan dibahas bersama anak hal ini sesuai dengan apa yang dikatakan Uno (2010: 158) dalam indikator memberikan pokokpokok materi.

2. Hasil observasi juga menunjukkan bahwa guru tidak memberitahu peraturan pelaksanaan kegiatan pembelajaran kepada anak sedangkan dari hasil angket guru sangat sering menginformasikan peraturan tata tertib atau aturan main saat pembelajaran. Menurut Uno (2010: 158), memberitahu peraturan pelaksaan kegiatan pembelajaran perlu dilakukan karena pembelajaran dapat berkualitas apabila salah satunya memenuhi dalam indikator memberi petunjuk belajar.

\section{SIMPULAN DAN SARAN}

\section{A. Simpulan}

Dari penelitian yang berjudul Pengaruh Kompetensi Profesional Guru Terhadap Kualitas Pembelajaran di RA Kecamatan Ciledug Kota Tangerang. dapat disimpulkan sebagai berikut: "Terdapat Pengaruh signifikan pada Kompetensi Profesional Guru terhadap Kualitas Pembelajaran di RA Kecamatan Ciledug Kota Tangerang dengan besaran pengaruh sebesar 49,3\%." Hal ini dapat berpengaruh karena guru merupakan salah satu kunci pembelajaran sehingga pembelajaran tersebut dapat berkualitas, dimana guru harus memiliki 4 kompetensi guru yang salah satunya adalah kompetensi profesional. Hal ini juga berpengaruh karena kompetensi profesional guru yang berada pada kategori sedang dan indikator kualitas pembelajaran berada pada kategori tinggi. Hasil frekuensi di atas juga didukung dari latar belakang guru yang didominasi lulusan $\mathrm{S} 1$ pendidikan. 


\section{B. Saran}

Berdasarkan hasil penelitian dan simpulan yang telah diuraikan di atas maka dapat diberikan beberapa saran yaitu:

1. Bagi guru

a. Meningkatkan penguasaan materi pembelajaran agar dapat menyampaikan materi secara tuntas.

b. Sebaiknya guru benar-benar melakukan PTK sesuai masalah yang ada di kelasnya sehingga masalah tersebut dapat diperbaiki.

c. Guru sebaiknya menerapkan tema dengan kehidupan sehari-hari anak agar sesuai dengan prinsip pembelajaran anak.

d. Guru sebaiknya memberitahukan peraturan dalam kegiatan pembelajaran agar tujuan pembelajaran dapat tercapai.

2. Bagi kepala sekolah sebaiknya dapat menindaklanjuti hasil evaluasi terhadap pengajaran yang dilakukan guru terkait proses kegiatan belajar mengajar (KBM) sesuai dengan pembelajaran anak usia dini untuk meningkatkan kompetensi profesional guru dan kualitas pembelajaran.

3. Bagi Dinas Pendidikan Kota Tangerang sebaiknya secara rutin melakukan program pelatihan terkait kemampuan cara mengajar dan penguasaan materi kepada guru.

4. Penelitian ini dapat dijadikan salah satu referensi untuk melakukan penelitian selanjutnya tentang kompetensi profesional atau upaya meningkatkan kualitas pembelajaran.

\section{DAFTAR PUSTAKA}

Budiharto. (2008). Metodologi Penelitian Kesehatan (Dengan Contoh Bidang Ilmu Kesehatan). Jakarta: EGC. Diakses dari EBook

https://books.google.co.id/books?id=KM5 oXuXCkC\&pg=PA29\&dq=metodologi $+\mathrm{p}$ enelitian+survei $\& h l=i d \& s a=X \& v e d=0 a h U$ KEwi8m7yUlNrVAhWCzLwKHTAvA7 MQ6AEIJjAA\# $\mathrm{v}=$ =nepage $\& \mathrm{q}=$ metodologi \%20penelitian\%20survei\&f=false
Emzir. (2012). Metodologi penelitian pendidikan kuantitatif dan kualitatif. Jakarta: Rajawali Press.

Hakiim, L. (2009). Perencanaan pembelajaran. Bandung: CV Wacana prima.

Mulyasa. (2009). Standar kompetensi dan sertifikasi guru. Bandung: PT Remaja Rosdakarya.

Musfah, J. (2015). Redesain pendidikan guru: teori, kebijakan, dan praktik. Jakarta: Prenada media Group.

Muslich, M., Maryaeni. (2009). Bagaimana menulis skripsi. Jakarta: PT Bumi Aksara.

Nurdin, S., Usman, B. (2002). Guru professional dan implementasi kurikulum. Jakarta: Ciputat pers.

Riyanto, Y. (2009). Paradigma baru pembelajaran. Jakarta: Kencana Prenada Media Group.

Permendikbud No.137 tahun 2014 tentang standar pendidikan anak usia dini.

Rohman, M., Amri, S. (2013). Strategi dan desain pengembangan system pembelajaran. Jakarta: Prestasi pustaka.

Rozak, A. (2010). pengembangan profesi guru. Jakarta: FITK UIN.

Sanjaya, W. (2011). Perencanaan dan desain sistem pembelajaran. Jakarta: Kencana.

Sudjana, N., Rivai, A. (2001). Media pengajaran. Bandung: CV. Sinar. Baru.

Sugiyono. (2007). Statistika untuk penelitian. Bandung: CV Alfabeta.

Trianto. (2011). Pengantar penelitian pendidikan bagi pengembangan profesi pendidikan dan tenaga kependidikan. Jakarta: Prenada media.

Uce, Loeziana. The golden age: masa efektif merancang kualitas anak. Jakarta: Fakultas Tarbiyah dan Keguruan UIN Ar- 
Raniry. Hal 78 -79 di akses ambil dari https://www.google.co.id/url?sa $=t \& r c t=j \&$ $\mathrm{q}=\&$ esrc $=\mathrm{s} \&$ source $=$ web $\& \mathrm{~cd}=1 \& \mathrm{cad}=\mathrm{rja}$ \&uact $=8 \&$ ved=0ahUKEwiL_qGJup7VAh XLFJQKHbxFCXUQFggiMAA\&url=http $\% 3 \mathrm{~A} \% 2 \mathrm{~F} \% 2$ Fjurnal.arraniry.ac.id\%2Find ex.php $\% 2$ Fbunayya $\% 2$ Farticle $\% 2 F$ downlo ad\%2F1322\%2F982\&usg=AFQjCNGMW bHE3jPslxFuGXhZ8vQek2At8w pada tanggal 23 Agustus 2017.
Uno, H.B. (2010). Model pembelajaran. Jakarta: Bumi aksara.

Uno, H.B. (2010). Perencanaan pembelajaran. Jakarta: PT Bumi Aksara.

Wahyuni, M., Yuliantina, I., Ritayanti, U. (2015). Penyusunan perencanaan pelaksanaan pembelajaran pendidikan anak usia dini. Jakarta: Direktorat Pembinaan Pendidikan Anak Usia Dini. 